\title{
TORTURE UNDER ENGLISH LAW
}

It is one of the proudest boasts of English jurisprudence that torture, in the strictest sense, has never had an official sanction in its courts. Like many other boasts it will not stand close scrutiny, for Peine Dure et Forte which will be spoken of hereafter, was frequently used and torture was often applied by other bodies than the Common Law courts, as in the court of Star Chamber and in the Privy Council.

It is a matter for satire that the formal declaration of the courts that torture was not a legal institution was forced on them by an insolent, though witty murderer. John Felton was the man. He had been convicted of the murder of George Villiers, Duke of Buckingham, favorite of Charles the First, and was brought before the Privy Council to be questioned, in an endeavor to obtain the names of accomplices and fellow conspirators. The Bishop of London suggested that he be tortured, to overcome his contumacy, on which he is reported to have replied, "If it must be so I cannot tell whom I might nominate in the extremity of torture, and if what I say then must go for truth, I would not say whether his Lordship" (meaning the Bishop of London), "or which of your Lordships I might name." He was asked no more questions but sent back to prison.

A few days later, on the fourteenth day of November, I628, a meeting of Judges was held to consider his case, and it was decided "that he ought not by law to be tortured on the rack, for no such punishment is known or allowed by our law."

Torture was in England an instrument of state and not of law. It was performed only under a warrant of the King, with his sign manual. Guy Fawkes, for instance, and other participants in the Gun Powder Conspiracy were tortured under a warrant signed by King James. The Tudor kings and queens had a fondness for it, and Hallam, the historian, says that "the rack seldom stood idle in the Tower, for all the latter part of Elizabeth's reign." 
The warrant coming from the King, the report of the evidence taken was made direct to him by the officials charged with the execution of the warrant for torture. The evidence was taken in three parts: before torture, in torture, and after torture. Francis Bacon acted as special examiner for the Crown in more than one case of torture. It was said that before a warrant could issue there must be "a vehement suspicion of guilt."

The torture used under the royal warrant was the rack-a good old-fashioned rack without any of the highly specialized improvements used elsewhere, such as the one used in Languedoc, which, in addition to the main rack which pulled the victim asunder by the feet and hands, had extra little racks devised to operate independently on each of his fingers and toes.

The ordinary rack was "an oblong frame of wood, slightly raised from the ground having at one end a fixed bar to which the legs were fastened and at the other a movable bar to which the hands were tied. By means of pulleys and levers this latter could be rolled on its own axis, thus straining the ropes till the sufferers joints were dislocated." It was introduced into England by the Duke of Exeter, constable of the Tower of London, in 1447 , and in his honour was known as "Exeter's Daughter."

Another generally used instrument was the Boot which was invented in Scotland. It was made "of iron or wood and iron fastened on the leg, between which and the boot wedges were driven by blows from a mallet. After each blow a question was put to the victim and the ordeal was continued until he gave the information or fainted." There was a similar torture which consisted of placing an iron boot on the victim's foot, and heating it until the questions were answered.

The Anglo-Saxon Chronicle, speaking of the troublous times of Stephen and Matilda, when there was no strong central government, and men said that "Christ and his saints slept," describes the torture used by the robber barons to extort plunder: "Then they took those whom they suspected of having goods . .. and put them in prison and tortured them with pains unspeakable, for never were martyrs tortured as were they. They hung some by their feet and smoked them with foul smoke; some 
by the thumbs or by the head and put burning things at their feet. They put a knotted string about their heads and twisted it until it went into their brains. They put them in dungeons where were adders, snakes and toads. . . There were hateful and grim things called Sachenteges . . . made thus; it was fastened to a beam having a sharp iron to go around a man's neck and throat, so that he may noways sit, nor lie, nor sleep."

Peine Dure et Forte has been mentioned as being in regular use in the English courts. It was not a means of extracting evidence from witnesses or of verifying testimony already given, as torture proper was; but it was a method employed to compel prisoners who "stood mute of malice," to plead guilty or not guilty to their indictment.

This seems a matter of small importance to us, but there was a technical rule of old English law which prevented the trial being proceeded with until the prisoner had pleaded. The exception was treason; in cases of which the refusal to plead was treated as a plea of guilty. The law also provided that the estate of persons sentenced to death and executed was forfeited to the Crown. Many persons who had property and relatives or dependents whom they wished to inherit that property refused to plead, knowing that if they died under torture instead of on the scaffold there was no forfeiture and their heirs received their estate.

Later, the courts attempted to remove the reason for the refusal to plead by incorporating in the order for torture, a clause which carried forfeiture of all the prisoner's goods. Even this, however, was not effective as there were still many prisoners who for various reasons refused to plead. Often it was a case of the prisoner not wishing his children to go through life under the stigma of having had their father hanged.

On the refusal to plead, an order was made for torture. In earlier times the order provided that the prisoner be returned to the prison, stripped naked, placed on the stone floor of his cell, without mattress, blanket, rushes or any other protection, his feet and arms stretched to the four corners of the cell and fastened 
to rings in the floor, and that he be left there until he was willing to plead or died. Once each day he was called upon to plead.

The first day he was given a small piece of barley bread to eat but nothing to drink; the second day he had nothing to eat but might have one drink of water "which lay nearest to the prison, so it was not running water"; and so on, a drink one day and a piece of bread the next until a plea, disease or starvation ended the ordeal.

The early system was found not to be drastic enough. Too many men had the courage and resolution to stick it out until they died, to suit the authorities; and the process was too protracted. There are records of men who lived for weeks, and one lived for forty days. The order was changed to provide that weights were to be laid upon the victim, bars of iron and slabs of stone, "as much as he could bear and more."

In I72I Nathaniel Hawes was arrested as a highwayman. He was something of a dandy, and when the prison authorities deprived him of his good clothes he refused to plead, because, as there was a good case against him, he knew he would be hanged, and he objected to a public appearance on the scaffold in a shabby suit. He bore two hundred and fifty pounds on his body for seven minutes and then pleaded-he was later hanged in his shabby clothes. A man named Spiggott lay under three hundred and fifty pounds for over an hour and only capitulated when an addition of fifty pounds was made to his burden.

In the case of Major Strangeways, accused of murder, who refused to plead in 1657 , when the weights had been applied, several cavalier friends, who had been allowed to witness the torture, jumped upon the iron bars and helped to put the victim out of misery.

The Peine Dure et Forte was a common practice at the Old Bailey, up to the Eighteenth Century. The last case recorded was in $174 \mathrm{I}$ at the Cambridge assizes where a prisoner died under the torture. It was abolished in $\mathrm{I772}$, when the courts were forced to rely solely upon what had been the alternative practice of tying the thumbs tightly together with whipcord until the pain forced the prisoner to speak. In 1828 the necessity for torture 
was removed by 7 and 8 George IV Chapter 28 , which provided that when a person "stood mute of malice," the Judge should enter a plea of "Not Guilty" on his behalf. That is the law today.

There is only one known instance of Peine Dure et Forte in America. At Salem in 1692 , one Giles Corey, on being arraigned on a charge of witchcraft, refused to plead, and was pressed to death during the torture.

Toronto, Canada.

Ernest G. Black. 